\title{
Vulnerability and Resilience of Tropical Forest Species to Land-Use Change
}

\author{
NIGEL E. STORK, ${ }^{*}$ JONATHAN A. CODDINGTON, $†$ ROBERT K. COLWELL, $\ddagger$ \\ ROBIN L. CHAZDON $\neq$ $\ddagger$ CHRISTOPHER W. DICK,$\S^{* *}$ CARLOS A. PERES,$\dagger \dagger$ \\ SEAN SLOAN, ${ }^{*}$ AND KATHY WILLIS $\neq \ddagger$
}

* Department of Resource Management and Geography, University of Melbourne, 500 Yarra Boulevard, Richmond, Victoria VIC 3121, Australia, email nstork@unimelb.edu.au †Department of Entomology, NHB 105, National Museum of Natural History, Smithsonian Institution, Washington, D.C. 20013-7012, U.S.A.

‡Department of Ecology and Evolutionary Biology, University of Connecticut, Storrs, CT 06269-3043, U.S.A.

$\S$ Department of Ecology and Evolutionary Biology and University Herbarium, University of Michigan, 830 North University Avenue, Ann Arbor, MI 48109-1048, U.S.A.

**Smithsonian Tropical Research Institute, P.O. Box 0843-03092, Balboa Ancón, Republic of Panamá ††School of Environmental Sciences, University of East Anglia, Norwich NR4 7TJ, United Kingdom ¥¥Oxford University Centre for the Environment, South Parks Road, Oxford OX2 7LE, United Kingdom

\begin{abstract}
We provide a cross-taxon and bistorical analysis of what makes tropical forest species vulnerable to extinction. Several traits have been important for species survival in the recent and distant geological past, including seed dormancy and vegetative growth in plants, small body size in mammals, and vagility in insects. For major past catastrophes, such as the five mass extinction events, large range size and vagility or dispersal were key to species survival. Traits that make some species more vulnerable to extinction are consistent across time scales. Terrestrial organisms, particularly animals, are more extinction prone than marine organisms. Plants that persist through dramatic changes often reproduce vegetatively and possess mechanisms of die back. Synergistic interactions between current antbropogenic threats, such as logging, fire, bunting, pests and diseases, and climate change are frequent. Rising temperatures threaten all organisms, perhaps particularly tropical organisms adapted to small temperature ranges and isolated by distance from suitable future climates. Mutualist species and trophic specialists may also be more threatened because of such range-shift gaps. Phylogenetically specialized groups may be collectively more prone to extinction than generalists. Characterization of tropical forest species' vulnerability to anthropogenic change is constrained by complex interactions among threats and by both taxonomic and ecological impediments, including gross undersampling of biotas and poor understanding of the spatial patterns of taxa at all scales.
\end{abstract}

Keywords: extinction vulnerability, range shifts, species traits, tropical forest species

Vulnerabilidad y Resiliencia de Especies de Bosques Tropicales al Cambio de Uso de Suelo

Resumen. Aportamos un análisis trans-taxón e bistórico de lo que bace que las especies de bosques tropicales sean vulnerables a la extinción. Varios atributos han sido importantes para la supervivencia de especies en el pasado reciente y geológico, incluyendo la latencia de semillas y el crecimiento vegetativo en plantas, el tamaño corporal pequeño de mamíferos y la vagilidad en insectos. Para las mayores catástrofes del pasado, como los cinco eventos de extinción masiva, la extensión del rango y la vagilidad o dispersión fueron claves para la supervivencia de especies. Los atributos que bacen que algunas especies sean más vulnerables a la extinción son consistentes a través de las escalas de tiempo. Los organismos terrestres, particularmente 
animales, son más propensos a la extinción que los organismos marinos. Las plantas que persisten a través de cambios dramáticos a menudo se reproducen vegetativamente y poseen mecanismos de muerte regresiva. Las interacciones sinérgicas entre amenazas antropogénicas actuales, como explotación de madera, fuego, cacería, plagas y enfermedades y cambio climático son frecuentes. Las temperaturas crecientes amenazan a todos los organismos, quizás particularmente a organismos tropicales adaptados a rangos de temperatura pequeños y aislados por distancia de climas futuros adecuados. Las especies mutualistas y los especialistas tróficos pueden estar más amenazados debidos a tales discontinuidades en los cambios de rango. Los grupos filogenéticamente especializados colectivamente pueden ser más propensos a la extinción que los generalistas. La caracterización de la vulnerabilidad de las especies de bosques tropicales al cambio antropogénico está limitada por las complejas interacciones entre amenazas y tanto por impedimentos taxonómicos y ecológicos, incluyendo el muestreo incompletos de biotas y el pobre entendimiento de los patrones espaciales de taxa a todas las escalas.

Palabras Clave: atributos de las especies, cambios de rango, especies de bosque tropical, vulnerabilidad de extinción

\section{Introduction}

Arguably $65-75 \%$ of all terrestrial species may be restricted to tropical forests. Approximately 50\% of all plants and vertebrates are believed to be endemic to 34 identified global biodiversity hotspots (Myers et al. 2000; Mittermeier et al. 2004). Most are in tropical forests. More than $50 \%$ of these forests have been severely degraded or converted for agriculture (FAO 2007), and this may have resulted in the loss of many species. The 2008 International Union for Conservation of Nature Red List considers roughly one-quarter to one-third of species in the best known groups (e.g., amphibians, birds, mammals, and gymnosperms) threatened with extinction in the near future (Fig. 1). Climate change poses additional threats to tropical forest species (Thomas et al. 2004; Laurance \& Peres 2006; Colwell et al. 2008), which potentially could be far more severe than in higher-latitude regions (Wright et al. 2009 [this issue]).

Since the early 1980 s many have warned of the potential loss of species through tropical forest loss and conversion (Myers 1979; Ehrlich \& Ehrlich 1981). Lack of evidence for the predicted mass extinctions (Brooks et al. 1999) may be due to our limited ability to detect extinctions, time lags before species become extinct (Diamond 1972), and the ability of secondary forests to retain high levels of primary forest biodiversity (Meijaard et al. 2005; Chazdon et al. 2009 [this issue]; but see Barlow et al. 2007). Singapore, for example, has lost many species (Turner et al. 1997; Brook et al. 2003; Sodhi \& Brook 2008) and may presage coming events in other tropical forests. We examined the traits that make tropical forest taxa prone to extinctions from anthropogenic causes and considered similarities and differences in such responses across taxa. We examined first the vulnerability of taxa in the geological past and then the possible synergistic effects of diverse extinction drivers acting on species (Peres 2001; Laurance 2006; Brook et al. 2008). We also considered current constraints to the understanding of vulnerability.

\section{Learning from the Past about Species Vulnerability and Resilience}

The fossil record shows that marine species with broad geographical ranges or widespread larval dispersal were especially likely to survive mass extinction events like the "big five" and smaller events (Jablonski 1995; Jackson 1995). Modern marine and terrestrial species are predicted to respond similarly (May et al. 1995). Nevertheless, perhaps $90-96 \%$ of all extinctions occurred outside such extinction events, presumably due to less understood and less globally catastrophic factors (May et al. 1995). Species longevity also varies among major

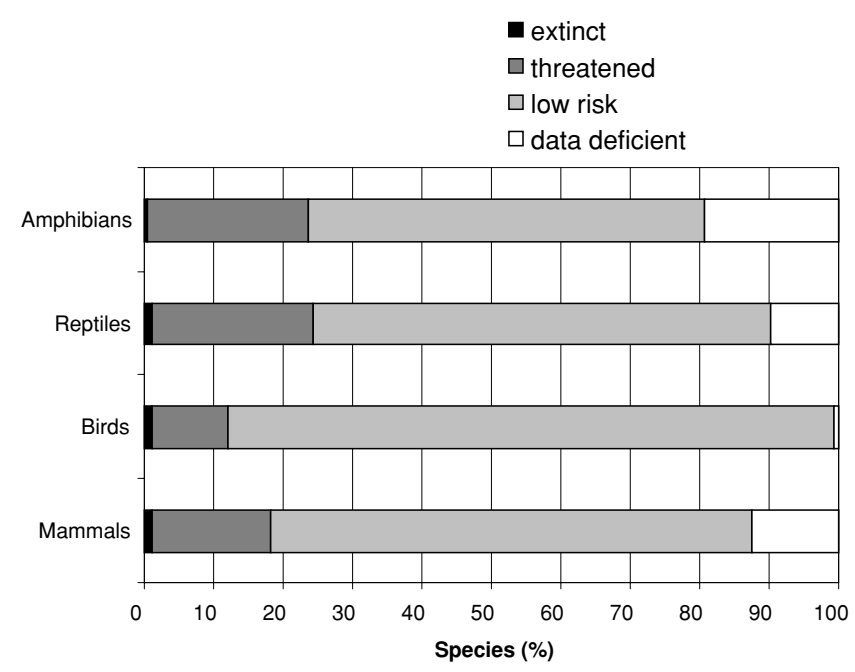

Figure 1. Proportions of species by threat category for four comprebensively assessed groups: amphibians, birds, mammals, and gymnosperms. Threat categories are extinct ( $E W$, extinct in the wild; $E X$, extinct), threatened (VU, vulnerable; EN, endangered; CR, critically endangered); low risk (LC, least concern; NT, near threatened), and data deficient (DD) (data from IUCN (2009). 
groups (Raup 1978; May et al. 1995): marine taxa endure longer (6-25 million years) than terrestrial taxa (1-4 million years) (McKinney 1997). McKinney (1997) also showed there is a high correlation between modern and fossil extinction rates; modern terrestrial taxa are more prone to extinction as in the past. Perhaps marine species have wider geographical ranges than terrestrial species (Norse 1993; McKinney 1997). Animals may also be much more prone to mass extinction than plants-the plant fossil record suggests fewer comparable extinction events than does the animal record (Willis \& McElwain 2002). Traits of persistent plant species include seed dormancy, underground vegetative reproduction, and dieback mechanisms (Knoll 1984; Willis \& Bennett 1995).

Over the last 1.8 million years temperature oscillations caused massive changes to the distribution of ecosystems and vegetation types, with many species becoming locally and some globally extinct. For this period Willis et al. (2004) concluded extinction exceeded speciation in many temperate groups. Although some therefore infer that the Ice Ages saw little net diversification (Zink et al. 2004), others infer major adaptive change, for example a modern temperate mammalian fauna rich in rapidly reproducing and generalist species (Lister 2004). On the basis of evidence from Southeast Asia, Meijaard et al. (2007) argue that geologically older vertebrate species are more vulnerable to climate fluctuations. These species tended to have smaller ranges and occupied fewer, smaller outlying islands than modern species.

Drought sensitivity strongly limits the distributions of tropical forest trees and other taxa (Engelbrecht et al. 2006). Lowland evergreen tropical forests contracted and tropical dry forests expanded during glacial periods in South and Central America, Africa, Australia, and Southeast Asia (Pennington et al. 2000; Morley 2000; Hugall et al. 2002). Increased warmth and rainfall due to contemporary climate change may further fragment highly threatened dry forests. Cover of Neotropical, wet, lowland forest was maintained through the Last Glacial Maximum in spite of globally reduced rainfall, reduced atmospheric $\mathrm{CO}_{2}$ concentrations, and cooling. Species composition, however, changed as upper-elevation taxa invaded the lowlands to create Ice Age tree communities with no modern analogs in Central and South America (e.g., Colinvaux et al. 1996; Piperno \& Jones 2003).

Severe historical forest fragmentation is best documented in Africa and Central America (Morley 2000). Africa has less forest than Amazonia (in part because the rainforests lack a protective montane rain shadow like the Andes) and has experienced severe extinctions of tree taxa. According to Morley (2000), African tree extinctions in the rainforest pulsed during the Eocene-Oligocene transition as savanna biomes became established and more recently and abruptly during the late Pliocene as forests contracted with Ice Age cooling and drying. Africa has notably low palm diversity compared with Asia and the Americas, probably due to the late Eocene and late Pliocene extinctions. In general, the smaller area over geological time of African tropical forests explains their relatively low regional species diversity compared with Asia and the Neotropics (Fine \& Ree 2006).

To comprehend one potential future of rain forests, consider the thermal maxima of the Miocene and Eocene, when atmospheric $\mathrm{CO}_{2}$ exceeded today's levels (1000 ppm) and those predicted over the next century (IPCC 2001; Hansen et al. 2008). Pollen cores show that tropical forests were more diverse (Morley 2000) and covered most of the world's landmasses, including Europe ("boreotropical forests") (Willis \& McElwain 2002). These rich, ancient forests may be a poor model for the future because extinctions could easily spike during the extraordinarily rapid climatic transition currently underway. Nevertheless, some populations of Neotropical, lowland, rainforest trees share common Miocene ancestors (Dick \& Heuertz, 2008); hence, tree populations can endure both warmth and climatic transitions. If such species retain their thermal tolerances to warmer climates, it will have been in spite of the generally cooler past several million years. Poleward range shifts of equatorial species due to global warming are unlikely given the prevailing narrow tropical temperature gradient today (Wright et al. 2009). Upslope elevational range shifts in the tropics are perhaps more likely (Colwell et al. 2008). But neither poleward nor elevational shifts of contemporary tropical species toward newly suitable areas can be expected if seed-dispersing animals decline through either anthropogenic habitat fragmentation or overhunting. As cloud levels rise on tropical mountains and climate zones shift upslope, human land-use patterns may well follow, further fragmenting the forest corridors essential for elevational range shifts for many species (Bush 2002).

Given projected global warming and anthropogenic land-use patterns, we suggest traits of species that make them particularly vulnerable to extinction. The narrow thermal tolerances characteristic of tropical species (Janzen 1967; Deutsch et al. 2008; Chen et al. 2009) should translate into narrow elevational ranges (McCain 2009). As climate change drives upslope range shifts, the lower elevational limit of narrow-ranged species may soon be forced beyond their current upper elevational limits. Colwell et al. (2008) project that over the next century half the plants and insects they studied on an elevational transect in Costa Rica are likely to experience such "range shift gaps," at least locally. Evidence from past climatic changes (e.g., Davis \& Shaw 2001; Bush \& Flenley 2007) make it clear that range shifts are routinely discordant and idiosyncratic, despite net shifts that tend to track climate zones (Wilson et al. 2007; Moritz et al. 2008; Chen et al. 2009). Species dependent on mutualisms (e.g., pollination, seed or fruit dispersal) and trophic specialists (e.g., insects requiring specific host plants) are therefore 
particularly likely to encounter obstacles in the case of range-shift gaps. Taxa with low physiological tolerances for higher temperatures or low genetic plasticity are similarly vulnerable (Hoffman et al 2003; Deutsch et al. 2008), as discussed by Wright et al. (2009). In the last 50,000 years, Homo sapiens and possibly other Homo species probably caused numerous extinctions, particularly by hunting large tropical vertebrates (Barnosky 2008), forest conversion, and wildfires (Piperno 2007). South America lost 50 megafauna genera, (reviewed in Koch \& Barnosky 2006) between 12,000 and 8,000 years ago (Barnosky 2008), mainly large and often slow-breeding mammals (Hubbe et al. 2007). All mammals larger than $320 \mathrm{~kg}$ and many between 320 and $100 \mathrm{~kg}$ went extinct. More recent human-induced extinctions are also common on tropical islands (Pimm et al. 2006).

\section{Vulnerability to Extinction and Depletion}

Many authors have attempted to identify extinctionprone traits (e.g., Lawton \& May 1995; Koh et al. 2004a,b; Brook et al. 2008; Sodhi et al. 2008a,b; Supporting Information), some from local or regional studies (e.g., Laurance 1991) and some from global analyses (e.g., Gaston \& Blackburn 1997; Cardillo et al. 2005). Most studies focus on birds or large mammals, rather than plants, invertebrates, or other organisms, and fewer attempt cross-taxon analyses of tropical forest taxon response to anthropogenic perturbation such as land-use change, hunting, or their synergies. McKinney (1997) showed that extinction is rarely random. Specialization results in nested extinction-prone traits in certain clades. Isolating simple ecological correlates of overall risk can be difficult because multiple mechanisms underlie extinction patterns (Owens \& Bennett 2000). In general, low population densities and fecundity, small ranges, low vagility, narrow niches, mature-forest habitat specificity, large body size, high species dependency for food or dispersal, and high trophic guild presage risk. These traits predominate among larger vertebrates, which are therefore more vulnerable. But vertebrate and other higher taxa vary widely within and between groups so that particular species respond quite divergently to threats. Lifehistory patterns, for example, vary dramatically across tropical forest vertebrates, plants, arthropods, fungi, and parasitic groups. Extinction vulnerability traits for plants and arthropods are little known (Supporting Information).

Extinction vulnerability increases if a species partially or entirely depends on another vulnerable organism (Stork \& Lyall 1993; Dunn 2005; Koh et al. 2004c). Obvious examples are parasites or host-specific herbivores. Whether herbivorous insects of tropical forests are more host specific (and therefore more vulnerable) than temperate taxa is hotly debated (Novotny et al. 2007; Dyer et al. 2007). Taxa with complex life histories or more than one host species would be even more vulnerable (Koh et al. 2004c). We considered one key complex set of threats, deforestation and fragmentation and wildfires, and their synergies with others such as climate change and invasive organisms. Hunting has been extensively covered elsewhere (e.g., Robinson \& Bennett 2000; Milner-Gulland et al. 2003) and is not addressed in detail here.

\section{Deforestation and Forest Degradation}

Primary forest habitat specificity or, conversely, tolerance to the open-habitat matrix strongly determines the probability of local extinction in tropical forest landscapes undergoing forest fragmentation and recurrent wildfires (Thomas 2004; Prugh et al 2008; Lees \& Peres 2009). Survival of old-growth species in secondary forest seems increasingly important as forests throughout the world regenerate (Chazdon et al. 2009). Many animals fare poorly in tropical forest fragments (Laurance 2008) and will not cross open clearings (e.g., some large mammals, Euglossine bees, Nymphalid butterflies, and birds: Dressler 1982; Herrera 1987; Barlow et al. 2007), although the latter is crucial to persistence in fragmented landscapes (Lees \& Peres 2009).

Singapore $\left(699.4 \mathrm{~km}^{2}\right)$ has lost $99.6 \%$ of its primary, lowland, evergreen rainforest to deforestation and fragmentation (Turner et al. 1997; Koh et al. 2004a; Sodhi et al. 2008a). Only secondary forest remains, covering $10-15 \%$ of the island. Sodhi et al. (2008a) evaluated 454 locally extinct versus 1430 extant terrestrial angiosperms for geographic distribution, pollination system, breeding system, growth form, habitat, height, fruit- or seed -dispersal mechanism and resprouting capacity, and other traits. These factors explained relatively little variation in extinction probability. Epiphytic, monoecious and hermaphroditic, inland forest specialists, and mammalpollinated species had higher probabilities of extinction. Dispersal traits, particularly small seed size and rapid seed production, correlate highly with establishment during post-disturbance succession. Animals disperse over $70 \%$ of tropical plant seeds (Howe \& Smallwood 1982). Scarcity of large frugivores in fragmented or overhunted forests favors wind-dispersed and small-seeded plants (Peres \& Palacios 2007; Cramer et al. 2007; Turner et al. 1997; Wright et al. 2007). Shade-tolerant, old-growth species with large seeds dispersed by large arboreal vertebrates are particularly vulnerable (Parry et al. 2007). Slow growth rates, low population densities, and low reproduction rates also increase risk following large-scale disturbances (see also Slik 2005 for further reference). Species able to persist in edge-dominated and secondary habitats exhibit fewer pollination systems, greater use of generalist diurnal vectors, and more hermaphroditism (Chazdon et al. 2003; Lopes et al. 2009). 
Recurrent surface wildfires are now one of the most important threats to seasonally dry tropical forests (Cochrane 2003), often acting synergistically with severe droughts. Wet tropical forest woody plants are typically thin barked and therefore vulnerable to even low "creeping" fires set by shifting cultivators (Barlow \& Peres 2004). Mast fruiting species such as Dipterocarpaceae in Southeast Asia are particularly susceptible because fires following recent recruitment events have drastic effects (van Nieuwstadt \& Sheil 2005). In Kalimantan even larger stemmed dipterocarp trees with bark thick enough to survive fire are still vulnerable to drought. Indeed, much of the plant mortality ascribed to fire is due to the severe droughts required before a forest can burn. Both larger and smaller species were vulnerable in different contexts, presumably depending on soil moisture and rooting depths. Small seedlings and nondeciduous canopy trees suffer if they cannot drop their leaves. Drought and fire together strongly affect the maintenance or recovery of forests and their role as carbon stores (van Nieuwstadt et al. 2001). Recurrent fires have changed forest structure and composition so that pioneers dominate the understory in some central-eastern Amazonia regions (Cochrane \& Schulze 1999; Barlow \& Peres 2008). Most guilds of birds decline after recurrent fires but arboreal granivores, frugivores, and nectarivores show unimodal responses, whereas arboreal gleaning insectivores increase (Barlow \& Peres 2004). For forest vertebrates, fire poses the greatest risk to primary forest specialists characterized by low mobility, poor climbing ability, poor flight capacity, small home ranges, or that rely heavily on woody shelters, such as cavity nests within hollow tree trunks (Peres et al. 2003).

\section{Synergistic Effects of Threats}

Increasing evidence suggests that different threats (such as fire and drought) act additively or synergistically and exacerbate species declines (Laurance 2006; Peres \& Michalski 2006; Brook et al. 2008). Brook et al. (2008) define synergistic as positive or multiplicative interactions that occur due to simultaneous action of separate processes (extrinsic threats or intrinsic biological traits). Synergies occur between almost all anthropogenic threats (Supporting Information). The lack of observed extinctions in tropical forests over the last 50 years may belie future exponential increases. For example, hunting often acts synergistically with other threats such as fragmentation and disease to cause local extinction (Peres 2001; Walsh et al. 2003). Climate change will likely power disease diffusion by altering host-pathogen interactions (Aguirre \& Tabor 2008). Logging increases forest fires and fragmentation and thus accentuates ecoclimatic stresses, species invasions, and edge-related change, which are often followed by hunting, trophic cascades (Spiller \& Schoener 1990; Pace et al. 1999), invasions of agricultural pests, and sometimes complete deforestation as colonists follow loggers into the forest frontier. Invasive organisms including those transported by humans or accentuated by climate change, can severely affect faunas naive to these new species or invasions. Predation by exotic species on islands has caused the extinctions of many native animals. In contrast, exotic plant invasions appear to have caused few island native plant extinctions (Sax \& Gaines 2008). The impact of chytrid fungus on amphibians (Pounds et al. 2006) is a particularly apt example of synergistic threats on a global basis.

The complexity of synergies complicates the identification of individual species traits that contribute to vulnerability or persistence. Sodhi et al. (2008b), however, showed that amphibians with small geographic ranges in areas with pronounced seasonality in temperature and precipitation are most likely to be on International Union for Conservation of Nature's Red List. Habitat loss and human densities also correlated with risk. In a similar study, Bradshaw et al. (2008) found that plant species that are more- "invasive" (e.g., climbing, herbaceous, and those that span multiple habitats and bioregions) are less threatened, whereas species that are tall, have tree-like forms, are range restricted, or inhabit lowland closed forest are more threatened. In some instances, different threats may affect different suites of species within a taxon but do not act synergistically. Owens and Bennett (2000) found that extinction risk in birds from hunting and persecution is associated with large body size and long generation time, but is not associated with habitat specialization, whereas extinction risk from habitat loss is associated with habitat specialization and small body size, but not generation time. In contrast, numerous examples show how different threats on the same landscape exhibit strong synergies (Supporting Information); presumably as yet unrecognized synergies await discovery.

\section{Constraints to Understanding the Extent of Vulnerability to Extinction in Tropical Forests}

Both taxonomic and ecological factors, including a paucity of tools for species identification, and severe undersampling, limit understanding of extinction-prone traits. For example, in western Amazonian forest plots, about $20 \%$ of midstory and canopy trees species are not identifiable to species; understory trees, woody lianas, epiphytes, and hemiepiphytes are ignored in most surveys (Ruokolainen et al. 2005). Consequently, research on regional forest dynamics is typically limited to large trees identified only to genus. One intensively studied 1-ha forest plot in Amazonian Ecuador contains 900 vascular plant species (Balslev et al. 1998), yet only 4000 plant species have been reported for the surrounding 7 million ha of Amazonian forest in Ecuador 
(Jørgensen \& León-Yánez 1999; Ruokolainen et al. 2005). Sampled floristic similarity across 122 sites in the same region ranged from zero overlap to more than $70 \%$ of species in common (Tuomisto et al. 2003). For many other groups the taxonomic impediment is even greater. Lawton et al. (1998), for example, showed that there is at least a 100-fold increase in the amount of taxonomic effort in measuring species richness of the smallest of nine taxonomic groups examined, the nematodes, compared with birds (see also Gardner et al. 2008 for further reference), yet nematodes, along with arthropods, microorganisms, and fungi, comprise the majority of global terrestrial species.

Inadequate sampling for almost all groups means the ranges of species and hence the patterns and measurement of beta-diversity are uncertain. Inadequate sampling inevitably underestimates local species richness and therefore range size, especially in richer biotas and poorly known groups (Colwell \& Hurtt 1994). The relatively recent development and widespread application of speciesrichness estimators (Colwell 2006) has for the first time allowed quantitative estimates of undersampling bias, and, at least for most tropical arthropod surveys, the bias seems considerable (Coddington et al. 2009). Local undersampling biases the calculation of pairwise similarity of species composition among samples (Chao et al. 2005,2006 ), the basis of many measures of beta diversity (Ruokolainen \& Tuomisto 2002; Ruokolainen et al. 2002); hence, undersampling underestimates alpha diversity and overestimates beta diversity. Patterns of alpha and beta diversity along elevational gradients are increasingly studied locally (e.g., Novotny et al. 2005; Brehm et al. 2007; Cardelús et al. 2006) and in meta-analyses (Rahbek 1995, 2005; McCain 2005). Given the conservation importance of elevational corridors as warming drives thermal zones upslope (Wilson et al. 2007; Colwell et al. 2008; Moritz et al. 2008; Raxworthy et al. 2008; Chen et al. 2009), these patterns require urgent study.

Although alpha-diversity estimates exist for a few groups, no "all species inventory" (sensu D. H. Janzen, see Yoon 1993) is available for any single tropical rainforest site, with the possible exception of Singapore (e.g., Brook et al. 2003). Without such measures of alpha and beta diversity, gamma-diversity estimates remain extremely imprecise. Determining the total range, variation, and maintenance of species composition at different locations (e.g., Tuomisto \& Ruokolainen 2006) is crucial to understanding extinction vulnerability. Relatively accurate distributional data and beta diversity estimates are available for terrestrial vertebrates in some regions (especially birds and mammals; e.g., Jetz \& Rahbek 2002; Rahbek et al. 2007; Rodriguez \& Arita 2004, Willig \& Gannon 1997), but comparable data for arthropods and other hyperdiverse groups are, at best, on much more local scales (e.g., Novotny et al. 2007; Brehm et al. 2007; Chen et al. 2009).
Ecological theory, largely based on vertebrates and woody plants, suggests that species ranges may be smaller in tropical forests (Janzen 1967; Ghalambor et al. 2006; Stevens 1989), at least on elevational gradients (Gaston \& Chown 1999; McCain 2009; R.K. C., unpublished). Yet, a lack of comparative data for different parts of the tropical world and for different taxa, particularly nonvertebrates and other smaller organisms, means the predicted pattern still awaits broad confirmation. In addition, how much range sizes and patterns of range overlap differ for different taxa, and hence whether species turnover rates differ, is largely unknown. Habitat fragmentation and other land-use patterns could differentially affect species with different range sizes (Lozada et al. 2008). Stochastic modeling of species distributions on large spatial scales combined with physical and climatic patterns (e.g., Storch et al. 2006; Rahbek et al. 2007; Rangel et al. 2007) provides a new approach to studying the drivers of diversity patterns that could be combined with human land-use patterns and the vulnerability of different taxa to probe the prospects for future extinctions.

Finally, recovering secondary forests may harbor many old-growth species (Norden et al. 2009; Chazdon et al. 2009), which offers some hope that primary forest species extinctions may not be as extensive as many fear. Determining whether taxa differ in extinction-relaxation times following forest conversion to other land uses will be key.

\section{Acknowledgments}

We thank S.J. Wright and W.M. Laurance for their invitation to participate in the Smithsonian Tropical Forest Institute workshop on tropical forest extinctions that led to the development of this paper. We thank T. Brooks for access to Fig. 1 and D. Sheil and three anonymous reviewers for valuable comments that improved this publication.

\section{Supporting Information}

Extinction vulnerability traits (Appendix S1) and effects of threats to biodiversity (Appendix S2) are available as part of the on-line article. The author is responsible for the content and functionality of these materials. Queries (other than absence of the material) should be directed to the corresponding author.

\section{Literature Cited}

Aguirre, A. A., and G. M. Tabor. 2008. Global factors driving emerging infectious diseases. Annals of the New York Academy of Sciences 1149:1-3.

Balslev, H., R. Valencia, G. Paz y Miño, H. Christensen, and I. Nielsen. 1998. Species count of vascular plants in one hectare of humid 
lowland forest in Amazonian Ecuador. Pages 585-594 in F. Dallmeier, and J. A. Comiskey, editors. Forest Biodiversity in North, Central and South America, and the Caribbean: Research and Monitoring. UNESCO, Paris.

Barlow, J., and C. A. Peres. 2004. Ecological responses to El Niño-induced surface fires in central Amazonia: management implications for flammable tropical forests. Philosophical Transactions of the Royal Society London Series B 359:367380.

Barlow, J., and C. A. Peres. 2008. Fire-mediated dieback and compositional cascade in an Amazonian forest. Philosophical Transactions of the Royal Society Series B 363:1787-1794.

Barlow, J., et al. 2007. Quantifying the biodiversity value of tropical primary, secondary and plantation forests. Proceedings of the National Academy of Sciences 47:18555-18560.

Barnosky, A. D. 2008. Megafauna biomass tradeoff as a driver of Quaternary and future extinctions. Proceedings of the National Academy of Sciences 105: 11543-11548.

Brehm, G., R. K. Colwell, and J. Kluge. 2007. The role of environment and mid-domain effect on moth species richness along a tropical elevational gradient. Global Ecology \& Biogeography 16:205219

Bradshaw, C. J. A., X. Giam, H. T. W. Tan, B. W. Brook, and N. S. Sodhi. 2008. Threat or invasive status in legumes is related to opposite extremes of the same ecological and life-history attributes. Journal of Ecology 96:869-883.

Brook, B. W., N. S. Sodhi, and P. K. L. Ng. 2003. Catastrophic extinctions follow deforestation in Singapore. Nature 424:420-423.

Brook, B. W., N. S Sodhi, and C. J. A. Bradshaw. 2008. Synergies among extinction drivers under global change. Trends in Ecology \& Evolution 23:453-460.

Brooks, T. M., S. L. Pimm, and J. O. Oyugi. 1999. Time lag between deforestation and bird extinction in tropical forest fragments. Conservation Biology 13:1140-1150.

Bush, M. B., 2002. Distributional change and conservation on the Andean flank: a palaeoecological perspective. Global Ecology and Biogeography 11:463-473.

Bush, M. B., and J. Flenley. 2007. Tropical rainforest responses to climatic change. Springer, New York.

Cardelús, C. L., R. K. Colwell, and J. E. Watkins. 2006. Vascular epiphyte distribution patterns: explaining the mid-elevation richness peak. Journal of Ecology 94:144-156.

Cardillo, M., G. M. Mace, K. E. Jones, J. Bielby, O. R. P. BinindaEdmonds, W. Sechrest, C. D. L. Orme, and A. Purvis. 2005. Multiple causes of high extinction risk in large mammal species. Science 309:1239-1241.

Chao, A., R. L. Chazdon, R. K. Colwell, and T.-J. Shen. 2005. A new statistical approach for assessing compositional similarity based on incidence and abundance data. Ecology Letters 8:148159.

Chao, A., R. L. Chazdon, R. K. Colwell, and T.-J. Shen. 2006. Abundancebased similarity indices and their estimation when there are unseen species in samples. Biometrics 62:361-371.

Chazdon, R. L., S. Careaga, C. Webb, and O. Vargas. 2003. Community and phylogenetic structure of reproductive traits of woody species in wet tropical forests. Ecological Monographs 73:331348.

Chazdon, R. L., C. A. Peres, D. Dent, D. Sheil, A. E. Lugo, D. Lamb, N. E. Stork, and S. Miller. 2009. The potential for species conservation in tropical secondary forests. Conservation Biology 23:1406-1417.

Chen, I.-C., H.J. Shiu, S. Benedick, J. D. Holloway, V. K. Chey, H. S. Barlow, J. K. Hill, and C. D. Thomas. 2009. Elevation increases in moth assemblages over 42 years on a tropical mountain. Proceedings of the National Academy of Sciences 106:1479-1483.

Cochrane, M. A. 2001. Synergistic interactions between habitat fragmenttation and fire in evergreen tropical forests. Conservation Biology 15:1515-1521.
Cochrane, M. A. 2003. Fire science for rainforests. Nature 421:913919.

Cochrane, M. A., and M. D. Schulze. 1999. Fire as a recurrent event in tropical forests of the eastern Amazon: effects on forest structure, biomass, and species composition. Biotropica 31:2-16.

Coddington, J. A., I. Agnarsson, J. M. Miller, M. Kuntner, and G. Hormiga. 2009. Undersampling bias: the null hypothesis for singleton species in tropical arthropod surveys. Journal of Animal Ecology 78:573-584.

Colinvaux, P. A., P. E. de Oliveira, J. E. Moreno, M. C. Miller, and M. B. Bush. 1996. A long pollen record from lowland Amazonia: forest and cooling in glacial times. Science 274:85-88.

Colwell, R. K. 2006. Estimates: statistical estimation of species richness and shared species from samples. Version 8.0. University of Connecticut, Storrs. Available from purl.oclc.org/estimates (accessed January 2009).

Colwell, R. K., G. Brehm, C. Cardelús, A. C. Gilman, and J. T. Longino. 2008. Global warming, elevational range shifts, and lowland biotic attrition in the wet tropics. Science 322:258-261.

Colwell, R. K., and G. C. Hurtt. 1994. Nonbiological gradients in species richness and a spurious Rapoport effect. The American Naturalist 144:570-595.

Cramer, J. M., R. C. G. Mesquita, and G. B. Williamson. 2007. Forest fragmentation differentially affects seed dispersal of large and smallseeded tropical trees. Biological Conservation 137:415-423.

Davis, M., and R. Shaw. 2001. Range shifts and adaptive responses to quaternary climate change. Science 292:673.

Deutsch, C. A., J. J. Tewksbury, R. B. Huey, K. S. Sheldon, C. K. Ghalambor, D. C. Haak, and P. R. Martin. 2008. Impacts of climate warming on terrestrial ectotherms across latitude. Proceedings of the National Academy of Sciences 105:6668.

Diamond, J. M. 1972. Biogeographic kinetics: estimation of relaxation times for avifaunas of southwest Pacific Islands. Proceedings of the National Academy of Sciences 69:3199-3204

Dick, C. W., and M. Heuertz 2008. The complex biogeographic history of a widespread tropical tree species. Evolution 62:2760-2774.

Dressler, R. L. 1982. Biology of the orchid bees (Euglossini). Annual Review of Ecology and Systematics 13:373-394.

Dunn, R. 2005. Modern extinctions, the neglected majority. Conservation Biology 19:130-136.

Dyer, L. A., et al. 2007. Host specificity of Lepidoptera in tropical and temperate forests. Nature 448:696-700.

Ehrlich, P. R., and E. H. Ehrlich. 1981. Extinction. The causes of the disappearance of species. Random House, New York.

Engelbrecht, B.M.J., L.S. Comita, R. Condit, et al. 2007. Drought sensitivity shapes species distribution patterns in tropical forests. Nature 447:80-83

FAO (Food and Agriculture Organization). 2007. State of the world's forests. FAO, Rome.

Fine, P. V. A., and R. H. Ree. 2006. Evidence for a time-integrated species-area effect on the latitudinal gradient in tree diversity. The American Naturalist 168:796-804.

Gardner, T. A., et al. 2008. The cost-effectiveness of biodiversity surveys in tropical forests. Ecology Letters 11:139-150.

Gaston, K. G., and T. M. Blackburn. 1997. Evolutionary age and risk of extinction in the global avifauna. Evolutionary Ecology 11, 557-565.

Gaston, K.G, and S. Chown. 1999. Why Rapoport's rule does not generalise. Oikos 84:309.

Ghalambor, C. R., P. Huey, J. Martin, J. Tewksbury, and G. Wang. 2006. Are mountain passes higher in the tropics? Janzen's hypothesis revisited. Integrative and Comparative Biology 46:5-17.

Hansen, J., M. Sato, P. Kharecha, D. Beerling, R. Berner, V. MassonDelmotte, M. Pagani, M. Raymo, D. L. Royer, and J. C. Zachos. 2008. Target atmospheric $\mathrm{CO}_{2}$ : where should humanity aim? The Open Atmospheric Science Journal 2:217-231.

Herrera, C. M. 1987. Component of pollinator 'quality': comparative analysis of a diverse insect assemblage. Oikos 50:79-80. 
Hoffman, A. A., R. J. Hallas, J. A. Dean, and M. Schiffer. 2003. Low potential for climate stress adaptation in a rainforest Drosophila species. Science 301:100-102.

Howe H. F., and J. Smallwood. 1982. Ecology of seed dispersal. Annual Review of Ecology and Systematics 13:201-228.

Hubbe, A., M. Hubbe, and W. Neves 2007. Early Holocene survival of megafauna in South America. Journal of Biogeography 34:1642-1646.

Hugall A., C. Moritz, A. Mousali, and J. Stanisic. 2002. Reconciling paleodistribution models and comparative phylogeography in the Wet Tropics rainforest land snail Gnarosophia bellendenkerensis (Brazier 1875). PNAS 99:6112-6117.

IPCC 2001. Climate Change 2001: The Scientific Basis. Contribution of Working Group I to the Third Assessment Report of the Intergovernmental Panel on Climate Change. Pages 1-881 in Houghton, J.T., Y. Ding, D.J. Griggs, M. Noguer, P.J. van der Linden, X. Dai, K. Maskell, and C.A. Johnson, editors. Cambridge University Press, Cambridge, United Kingdom and New York.

IUCN (International Union for Conservation of Nature). 2009. Table $3 a-$ Summary of number of animal species in each Red List Category in each taxonomic class. IUCN, Gland, Switzerland. Available from http://www.iucnredlist.org/static/stats (accessed July 2009).

Jablonski, D. 1995. Extinctions in the fossil record. Pages 25-44 in J. H. Lawton and R. M. May, editors. Extinction rates. Oxford University Press, Oxford, United Kingdom.

Jackson, J. 1995. Constancy and change of life in the sea. Pages 45-54 in J. H. Lawton and R. M. May, editors. Extinction rates. Oxford University Press, Oxford, United Kingdom.

Janzen, D. H. 1967. Why mountain passes are higher in the tropics. The American Naturalist 101:233-249.

Jetz, W., and C. Rahbek. 2002. Geographic range size and determinants avian species richness. Science 279:1548-1551.

Jørgensen, P. M., and S. León-Yánez. 1999. Catalogue of the vascular plants of Ecuador. Missouri Botanical Garden, St. Louis.

Koch, P. L., and Barnosky, A. D. 2006. Late Quaternary extinctions: state of the debate. Annual Reviews of Ecology and Systematics 37:215-250.

Koh, L. P., N. S. Sodhi, and B. W. Brook. 2004a. Ecological correlates of extinction proneness in tropical butterflies. Conservation Biology 18:1571-1578.

Koh, L. P., N. S. Sodhi, and B. W. Brook. 2004b. Co-extinctions of tropical butterflies and their host plants. Biotropica 36:272-276.

Koh L. P., R. R. Dunn, N. S. Sodhi, R. K. Colwell, H.C Proctor, and V. S. Smith. 2004c. Species co-extinctions and the biodiversity crisis. Science 305:1632-1634.

Knoll, A. H. 1984. Patterns of extinction in the fossil record of vascular plants. Pages 21-69 in M. H. Nitecki, editor. Extinctions. University of Chicago Press, Chicago.

Lawton, J. H., and R. M. May. 1995. Extinction rates. Oxford University Press, Oxford, United Kingdom.

Lawton, J. H., et al. 1998. Biodiversity inventories, indicator taxa and effects of habitat modification in tropical forest. Nature 391:72-76.

Laurance, W. F. 1991. Ecological correlates of extinction proneness in Australian tropical rain forest mammals. Biological Conservation 5:79-89.

Laurance, W. F. 2006. Fragments and fire: alarming synergisms among forest disturbance, local climate change, and burning in the Amazon. Pages 87-104 in W. F. Laurance and C. A. Peres, editors. Emerging threats to tropical forests. University of Chicago Press, Chicago.

Laurance, W. F. 2008. Theory meets reality: how habitat fragmentation research has transcended island biogeographic theory. Biological Conservation 141:1731-1744.

Laurance, W. F., and C. A. Peres, editors. 2006. Emerging threats to tropical forests. University of Chicago Press, Chicago.

Lees, A. C., and C. A. Peres. 2009. Gap-crossing movements predict species occupancy in Amazonian forest fragments. Oikos 118:280-290.
Lister, A. M. 2004. The impact of Quaternary Ice Ages on mammalian evolution. Philosophical Transactions of the Royal Society of London, B 359:221-241. DOI 10.1098/rstb.2003.1436.

Lopes, A. V., L. C. Girão, B. A. Santos, C. A. Peres, and M. Tabarelli. 2009. Long-term erosion of tree reproductive trait diversity in edgedominated Atlantic forest fragments. Biological Conservation DOI: 10.1016/j.biocon.2009.01.007.

Lozada, T., G. de Koning, M. Kessler, A. Klein, and T. Tscharntke. 2008. Geographical range size of tropical plants influences their response to anthropogenic activities. Diversity and Distributions 14:5968.

May, R.M., J.H. Lawton, and N.E. Stork. 1995. Assessing extinction rates. Pages 1-24 in J. H. Lawton and R. M. May, editors. Extinction rates. Oxford University Press, Oxford, United Kingdom.

McCain, C. 2005. Elevational gradients in diversity of small mammals. Ecology 86:366-372.

McCain, C. M. 2009. Vertebrate range sizes indicate that mountains may be "higher" in the tropics. Ecology Letters 12:550-560.

McKinney, M. L. 1997. Extinction vulnerability and selectivity: combining ecological and paleontological reviews. Annual Review of Ecology and Systematics 28:493-516.

Meijaard E., et al. 2005. Life after logging: reconciling wildlife conservation and production forestry in Indonesian Borneo. Center for International Forestry Research, Bogor, Indonesia.

Meijaard, E., D. Sheil, R. Nasi, and S. A. Stanley. 2006. Wildlife conservation in Bornean timber concessions. Ecology and Society 11: http://www.ecologyandsociety.org/vol11/iss1/art47/.

Meijaard E., D. Sheil, A. J. Marshall, and R. Nasi. 2007. Phylogenetic age is positively correlated with sensitivity to timber harvest in Bornean mammals. Biotropica 40:76-85.

Milner-Gulland, E. J., E. L. Bennett, and the SCB 2002 Annual Meeting Wild Meat Group. 2003. Wild meat-the bigger picture. Trends in Ecology \& Evolution 18:351-357.

Mittermeier, R. A., P. Robles Gil, M. Hoffmann, J. Pilgrim, T. Brooks, C. G. Mittermeier, J. Lamoreux, and G. A. B. da Fonseca. 2004. Hotspots: revisited. Cemex books on Nature, Mexico City, D. F.

Moritz, C., J. Patton, C. Conroy, J. Parra, G. White, and S. Beissinger. 2008. Impact of a century of climate change on small-mammal communities in Yosemite National Park, USA. Science 322:261.

Morley, R. J. 2000. Origin and evolution of tropical rain forests. John Wiley \& Sons, West Sussex, United Kingdom.

Myers, N. 1979. The sinking ark. A new look at the problem of disappearing species. Pergamon, New York.

Myers, N., R. A. Mittermeier, C. G. Mittermeier, G. A. da Fonseca, and J. Kent. 2000. Biodiversity hotspots for conservation priorities. Nature 403:853-858.

Norden, N., R. L. Chazdon, A. Chao, Y.-H. Jiang, and B. Vílchez-Alvarado. 2009. Resilience of tropical rain forests: tree community reassembly in secondary forests. Ecology Letters 12:385-394.

Norse, E., editor. 1993. Global marine biological diversity. Island Press, Washington, D.C.

Novotny, V., S. Miller, Y. Basset, L. Cizek, K. Darrow, B. Kaupa, J. Kua, and G. Weiblen. 2005. An altitudinal comparison of caterpillar (Lepidoptera) assemblages on Ficus trees in Papua New Guinea. Journal of Biogeography 32:1303-1314.

Novotny, V., et al. 2007. Low beta diversity of herbivorous insects in tropical forests. Nature 448:692-695.

Owens, I. P. F., and P. M. Bennett. 2000. Ecological basis of extinction risk in birds: habitat loss versus human persecution and introduced predators. Proceedings of the National Academy of Sciences 97:12144-12148.

Pace, M., J. J. Cole, S. R. Carpenter, and J. F. Kitchell. 1999. Tropic cascades revealed in diverse ecosystems. Trends in Ecology \& Evolution 14:483-488.

Parry, L., J. Barlow, and C. A. Peres. 2007. The conservation value of secondary forests for large vertebrates in the Brazilian Amazon. Journal of Tropical Ecology 23:653-662. 
Pennington, R. T., D. E. Prado, and C. A. Pendry. 2000. Neotropical seasonally dry forests and Quaternary vegetation changes. Journal of Biogeography 27:261-273.

Peres, C. A. 2001. Synergistic effects of subsistence hunting and habitat fragmentation on Amazonian forest vertebrates. Conservation Biology 15:1490-1505.

Peres, C. A., J. Barlow, and T. Haugaasen. 2003. Vertebrate responses to surface fires in Amazonian forests. Oryx 37:97-109.

Peres, C. A., and F. Michalski. 2006. Synergistic effects of habitat disturbance and hunting in Amazonian forest fragments. Pages 105-126 in W. F. Laurance and C. A. Peres, editors. Emerging threats to tropical forests. University of Chicago Press, Chicago, Illinois.

Peres C. A., and E. Palacios. 2007. Basin-wide effects of game harvest on vertebrate population densities in Amazonian forests: implications for animal-mediated seed dispersal. Biotropica 39:304315.

Pimm, S. L., P. Raven, A. Peterson, C. H. Şekercioğlu, and P. Ehrlich. 2006. Human impacts on the rates of recent, present and future bird extinctions. Proceedings of the National Academy of Sciences 103:10941-10946.

Piperno, D. R. 2007. Prehistoric human occupation and impacts on Neotropical forest landscapes during the Late Pleistocene and Early/Middle Holocene. Pages 193-21 in M. Bush and J. R. Flenley, editors. Tropical rainforest responses to climate change. SpringerVerlag, New York.

Piperno, D. R., and J. G. Jones. 2003. Paleoecological and archaeological implications of a Late Pleistocene/Early Holocene record of vegetation and climate from the Pacific coastal plain of Panama. Quaternary Research 59:79-87.

Pounds, J. A., et al. 2006. Widespread amphibian exctintions from epidemic disease driven by global warming. Science 439:161167.

Prugh, L. R., K. E. Hodges, A. R. E. Sinclair, and J. S. Brashares. 2008. Effect of habitat area and isolation on fragmented animal populations. Proceedings of the National Academy of Science 105:20770-20775.

Rahbek, C. 1995. The elevational gradient of species richness: a uniform pattern? Ecography 19:200-205.

Rahbek, C. 2005. The role of spatial scale in the perception perception of large-scale species-richness patterns. Ecology Letters 8:224-239.

Rahbek, C., N. Gotelli, R. K. Colwell, G. L. Entsminger, T. F. L. V. B. Rangel, and G. R. Graves. 2007. Predicting continental-scale patterns of bird species richness with spatially explicit models. Proceedings of the Royal Society of London Series B 274:165-174.

Rangel, T. F. L. V. B., J. A. F. Diniz-Filho, and R. K. Colwell. 2007. Species richness and evolutionary niche dynamics: a spatial patternoriented simulation experiment. The American Naturalist 170:602616.

Raup, D.M. 1978. Cohort analysis of generic survivorship. Paleobiology 4:1-15.

Raxworthy, C. J., R. G. Pearson, N. Rabibisoa, A. M. Rakotondrazafy, J.-B. Ramanamanjato, A. P. Raselimanana, S. Wu, R. S. Nussbaum, and D. A. Stone. 2008. Extinction vulnerability of tropical montane endemism from warming and upslope displacement: a preliminary appraisal for the highest massif in Madagascar. Global Change Biology 14:1703-1720.

Robinson, J. G., and E. L. Bennett, editors. 2000. Hunting for sustainability in tropical forests. Columbia University Press, New York.

Rodriguez, P., and H. T. Arita. 2004. Beta diversity and latitude in North American mammals: testing the hypothesis of covarition. Ecography 27:1-11.

Ruokolainen, K., and H. Tuomisto. 2002. Beta-diversity in tropical forests. Science 297:1439a.

Ruokolainen, K., H. Tuomisto, J. Vormisto, and N. Pitman. 2002. Two biases in estimating range sizes of Amazonian plant species. Journal of Tropical Ecology 18:935-942.

Ruokolainen, K., H. Tuomisto, and R. Kalliola. 2005. Landscape heterogeneity and species diversity in Amazonia. Pages 251-270 in E.
Bermingham, C. W. Dick, and C. Moritz, editors. Tropical rainforests: past, present and future. University of Chicago Press, Chicago, Illinois.

Sax, D. F., and S. D. Gaines. 2008. Species invasions and extinction: the future of native biodiversity on islands. Proceedings of the National Academy of Sciences 105:11490-11497.

Slik, J. W. F. 2005. Assessing tropical lowland forest disturbance using plant morphological and ecological attributes. Forest Ecology and Management 205:241-250.

Sodhi, N. S., and B. W. Brook. 2008. Fragile Southeast Asian biotas. Biological Conservation 141:883-884.

Sodhi, N. S., et al. 2008a. Correlates of extinction proneness in tropical angiosperms. Diversity and Distributions 14:1-10.

Sodhi, N. S., D. Bickford, A. C. Diesmos, T. M. Lee, L. P. Koh, C. H. Sekercioglu, and C. J. A. Bradshaw. 2008b. Measuring the meltdown: drivers of global amphibian extinction and decline. Public Library of Science ONE DOI:10.1371/journal.pone.0001636.

Spiller, D. A., and T. W. Schoener. 1990. A terrestrial field experiement showing the impact of removing top predators on foliage damage. Nature 347:469-472.

Stevens, G. C. 1989. The latitudinal gradient in geographical range: how so many species coexist in the tropics. The American Naturalist 133:240-256.

Storch, D., et al. 2006. Energy, range dynamics and global species richness patterns: reconciling mid-domain effects and environmental determinants of avian diversity. Ecology Letters 9:1308-1320.

Stork, N. E., and C. H. C. Lyal. 1993. Extinction or "co-extinction" rates. Nature 366:307.

Thomas, C. D., et al. 2004. Extinction risk from climate change. Nature 427:145-148.

Thomas, S. C. 2004. Ecological correlates of tree species persistence in tropical forest fragments. Pages 279-313 in E. C. Losos and E. G. J. Leigh, editors. Tropical forest diversity and dynamism: findings from a large-scale plot network. University of Chicago Press, Chicago, Illinois.

Tuomisto, H., K. Ruokolainen, and M. Yli-Halla. 2003. Dispersal, environment, and floristic variation of Western Amazonian forests. Science 299:241-244.

Tuomisto H., and K. Ruokolainen. 2006. Analyzing or explaining beta diversity? Understanding the targets of different methods of analysis Ecology 87:2697-2708.

Turner, I. M., Y. K. Wong, P. T. Chew, and A. bin Ibrahim. 1997. Tree species richness in primary and old secondary tropical forest in Singapore. Biodiversity and Conservation 6:537-543.

van Nieuwstadt, M. G. L., D. Sheil, and K. Kartawinata. 2001 The ecological consequences of logging in the burned forests of East Kalimantan, Indonesia. Conservation Biology 15:11831186.

van Nieuwstadt, M. G. L., and D. Sheil. 2005. Drought, fire and tree survival in a Borneo rain forest, East Kalimantan, Indonesia. Journal of Ecology 93:191-201.

Walsh, P. D., et al. 2003. Catastrophic ape decline in western equatorial Africa. Nature 422:611-614.

Willig, M. R., and M. R. Gannon. 1997. Gradients of species diversity and turnover in marsupials: a hemispheric perspective. Journal of Mammalogy 78:756-765.

Willis, K. J., L. Gillson, and T. M. Brncic. 2004. How 'virgin' is virgin rainforest? Science 304:402-403.

Willis, K. J., and K. D. Bennett. 1995. Mass extinction, Punctuated equilibrium and the fossil plant record. Trends in Ecology \& Evolution 10:308-309.

Willis, K. J., and J. C. McElwain. 2002. The evolution of plants. Oxford University Press, Oxford, United Kingdom.

Wilson, R. J., D. Gutierrez, J. Gutierrez, and V. Monserrat. 2007. An elevational shift in butterfly species richness and composition accompanying recent climate change. Global Change Biology 13:1873-1887. 
Wright, S. J., A. Hernandez, and R. Condit. 2007. The bushmeat harvest alters seedling banks by favoring lianas, large seeds, and seeds dispersed by bats, birds, and wind. Biotropica 39:363-371.

Wright, S. J., H. C. Muller-Landau, and J. Schipper. 2009. The future of tropical species on a warmer planet. Conservation Biology 23:1418-1426.
Zink, R. M., J. Klicka, and B. R. Barber. 2004. The tempo of avian diversification during the Quaternary. Philosophical Transactions of the Royal Society of London, B 359:215-220. DOI 10.1098/rstb.2003.1392.

Yoon, C. K. 1993. Counting creatures great and small. Science 260:620-622.

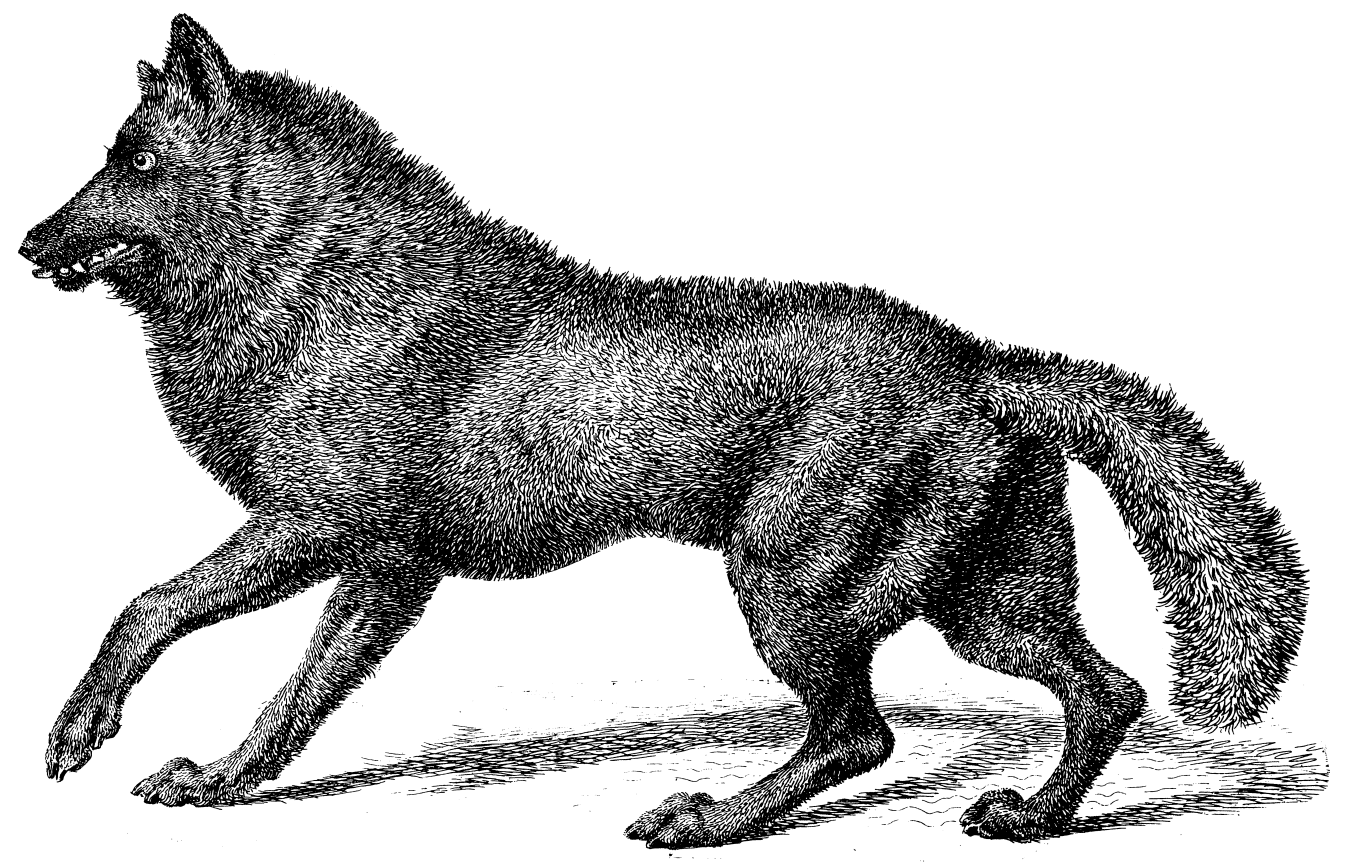

